\title{
Common sense as political struggle: asserting the right to home following the Grenfell Tower fire
}

\begin{abstract}
The Grenfell Tower fire is a tragic manifestation of the brutality of the neoliberal conditionality of home. The systematic devaluing of the lives of residents in the social housing block is the result of stigmatisation-fuelled neglect. This paper explores the ideological formation of the 'ideals' of home ownership, asserting a right to home as a means to resist the 'unequal distribution of precarity' that defines neoliberal formations of home.
\end{abstract}

Key words: Social housing, right to home, precarity, austerity, neoliberal common sense

\section{Introduction}

There were 129 homes in Grenfell Tower, yet the question of how many lives were lost on the $14^{\text {th }}$ June remains unanswered. As I write, it is believed at least 80 people were killed in the fire which devastated the 24-storey social housing block. Survivors from 106 of the flats have helped shape a picture of who lived there and who may have been visiting. Nevertheless, with no survivors yet to be found from 23 flats, this picture is unlikely to represent the true scale of this tragic event. The invisibility of the lives of the residents of Grenfell Tower is symptomatic of the 'symbolic inequality of people being unheard, silenced and dismissed' (Humphrey, 2017), of 'not counting; and not even being properly counted' (Watt, 2017a). The materiality of the tower, the design, form and condition, which contributed to the scale of the fire is a manifestation of 'decades of stigmatisation-fuelled neglect' (Madden, 2017) whereby the social inequalities 'objectified in physical space are reproduced in thought and language' (Garbin and Millington, 2012: 4), in the symbolic stigma attached to social housing (Hancock and Mooney, 2013). The systemic devaluing of the lives of residents inherent in the failure of Kensington and Chelsea Tenant Management Organisation to respond to safety concerns and to carry out basic maintenance represents an 'unequal distribution of precarity' (Butler, 2012), a process enacted by governmental and economic institutions to instil populations with a sense insecurity and hopelessness (Butler, 2011). As Madden (2017) sadly reflects, the level of deadly risk residents encountered in their everyday lives focusses our attention on the fact that hierarchised statuses of class, race and tenure still determine 'whose life is grievable and worth protecting and whose life is ungrievable....and thus less worth of protection' (Butler, 2012: 148).

Precarity is a structure of affect foregrounding interdependency, no individual suffers precarity without structural failures to safeguard against that possibility (Butler, 2011: 2). Therefore, the precarity of home is a condition uniting private renters and council tenants within the 'new logics of expulsion' (Sassen, 2014), with eviction and displacement now routine in London (Watt, 2017a). The Grenfell Tower fire has revealed 'injustices, deprivations, expulsions and brutalities', however, it has also awakened resistance as residents reject the 'dominant expulsionary logic' (Watt, 2017a) that defines neoliberal conditionality of access to home.

Through an analysis of the housing market as neoliberal common sense, this paper aims to foreground the 'strangely composite' (Hall and O'Shea, 2013) nature of this logic, reconceptualising common sense as a site of politics (Rancière, 1999). As politics, common sense may be understood as a site of dissensus and, as such, a productive site. Reflecting upon one moment of dissensus, where a local resident voiced their response to the fire (BBC, 2017), I argue that the visibility of such critiques across social media 
may rupture and transform 'ways of doing, ways of being, and ways of saying' (Rancière, 1999) within contemporary imaginaries of housing. A focus on moments of dissensus, foreground everyday resistances. As a space where value is redefined, they may exemplify relations of equality that are lacking in the economic and political domain (Butler and Athanasiou, 2013). I argue that by locating the Grenfell Tower fire within processes of gentrification and the systemic devaluing of classed and raced lives, residents' voices may rupture the neoliberal common sense replacing 'individualistic values with an alternative ethic of equality and care' (Humphrey, 2017).

This paper suggests that such an ethic of equality is encapsulated in the notion of a right to home. Through the exposure of precarity enacted through the structural conditionality of home, the Grenfell Tower fire has foregrounded the urgency to recognise those beyond the logics of capitalist modes of production as embodying the rights to home.

\section{Social housing and access to home}

Housing benefit reforms in the UK are central to the Conservative government's austerity policy characterised by an 'unprecedented retraction of welfare support' (Powell, 2015: 321). Yet, these more recent housing policy shifts are part of a broader ideological project to reconceptualise housing through the logic of the housing market (Kadi, 2015). Central to the legitimation of neoliberal policies are processes of 'class decomposition through individualization' (Tyler, 2015). As such, housing benefit reforms must be situated within the context of neoliberal 'state crafting' (Wacquant, 2010), a process of 'intense ideological work' (Jensen, 2014: 2.1) where 'ruling ideas' of the 'undeserving poor' become formative of discursive repertoires of selfhood (Shildrick and MacDonald, 2013). Defined by the stimulation of competition over resources in all aspects of social life, neoliberal policy may be traced through 'intensive forms of government' (Tyler, 2015) which aim to enable and protect private property rights, free markets and free trade (Harvey, 2005). Analysis of the social, material and political construction of social housing within contemporary neoliberal housing policy highlights the processes through which being housed in social housing such as Grenfell Tower comes to signify a position of 'valuelessness' (Skeggs, 2004)

Housing policy is entrenched in discourses of deserving and undeserving, the positioning of the citizen within constructions of individual and societal 'success' (Crawford and McKee, 2018). The physical locating of classed groups within geographies of social housing, therefore, cannot be disconnected from the social locating this entails. Hanley (2007) traces the material and social construction of council estates, from the paternalism of the discourse and practice of slum clearances, to the 'homes fit for heroes' of the inter-war years, the ongoing disinvestment and non-standard (sub-standard) construction, to the cultural devaluing of social housing through the redefining of citizenship as imagined through the 'Right-to-Buy'.

Through making explicit the processes through which one comes to live in social housing, Hanley's account of being 'housed' makes visible unequal access to neoliberal formations of precarious citizenship. When read through the neoliberal optic which values choice as an expression of the self, being 'housed' distances the individual from contemporary formations of selfhood (Featherstone, 2013). To be 'housed' in social housing is a process beyond one's control, unstable and unpredictable. It is within this logic of a market engaged citizenry achieved through home ownership, that those living in social housing are positioned beyond the rights to home, as abject 'failed' citizens (Tyler, 2013).

The effect of these political manifestations is a process of dehumanisation of the benefit poor, a stripping away of the rights embodied in the market engaged citizenry; the right to home, the right to history, the right to community (Hubbard and Lees, 2018). Discourses of anti-welfare (Hancock and Mooney, 2013) 
have produced an assessment of those in receipt of benefits as un-located in social histories and responsibilities. Representations of the claimant, the benefit cheat, the jobless, take the individual as the site of welfare. This dislocation of the benefit poor from their social embeddedness, individualises their position as a personal failure and denies the role of the social in the well-being of a people. Those in receipt of benefits have no right to home, they are assumed to have no emotional attachment to their place, no connections with family and friends, they are to 'be housed' given the measured requirements of their household. There is a dislocation of families from a sense of trajectory, they are defined, reified at the point of assessment; there is no space for complexity (Moffatt et al, 2015). Under these policies, a sense of history, belonging and community are re-imagined as privilege, accentuating 'the negative process of marginalisation and stigmatization (both social and spatial) for the least powerful' (Powell, 2015: 321). As Watt evokes, home in this context is 'less a place of security than of gnawing existential angst' (Watt, 2017a), where being housed involves a 'dystopian "un-merry-go-round" of enforced mobility, insecurity and anxiety' (Watt, 2017b: 7).

Therefore, formations of neoliberal housing policy are characterised not simply by the withdrawal of welfare, rather a 'punitive, coercive state' (Watt, 2017b: 5) acts as a 'generative force in respect to marginality, inequality and precarity' (Slater, 2013: 964). The success of political agendas requires the cultivation of national affect, harnessing 'stigmatising discourse which ties in with hegemonic mass media representations' (Watt, 2017b: 5), to present ideologically driven policies as common sense solutions (Jacobs and Manzi, 2013).

\section{The housing market as neoliberal common sense}

The assault on the right to home, manifest in the material neglect of both the people and place of Grenfell Tower, is legitimised through the crafting of an 'anti-welfare commonsense' (Jensen, 2014) centring on the neoliberal formation of housing as market. The political construction of housing aspirations for home ownership through a process of 'othering' alternative tenures is central to the Conservative revisionist agenda of social housing. The delegitimization of social housing is enacted in The Localism Act 2011, which grants social landlords in England the right to award fixed-term tenancies (Robinson and Walshaw, 2014). The security of tenure is fundamental to the understanding of social housing as home, providing 'a source of stability that helps to mediate the precariousness of life on low incomes' (Robinson and Walshaw, 2014: 1). Despite the role social housing plays 'as a social good', the removal of the security of tenure is recast within a Conservative rhetoric of liberating tenants from the 'trap' of 'dependency' (Robinson and Walshaw, 2014: 3).

Sociological analyses trace the ideological politics embedding austerity as the 'common sense' answer to the 'question' of welfare since the 2008 global financial crisis and subsequent recession (Jensen, 2014: 2.1). Furthering Clarke and Newman's (2012) analysis of the 'alchemy of austerity', Jensen draws connections between political discursive repertoires, such as 'Big Society' and 'Broken Britain', and media representations of 'poverty porn', as 'creating new forms of neoliberal commonsense [sic] around welfare and social security' (Jensen, 2014: 1).

This new common sense, centred on the "immensely powerful binary of "skiver" and "striver" conceives of its citizens as one or the other, occupying different spaces, oriented by different morals, aspirations and values' (Jensen, 2014: 2.5). It is the dislocation of such discourses from the social, political and economic structuring of the context of austerity that reinforces the 'common sense' of these claims; common sense 'seems to be outside time... [i]ndeed it may be persuasive precisely because we think of it as a product of Nature rather than of history' (Hall and O'Shea, 2013: 2). 
Nevertheless, there is an incoherence within this revisionist agenda that is symptomatic of the inadequacies of neoliberal housing policies. Powell (2015) argues cuts to Local Housing Allowance, the regime for administering Housing Benefit for those living in private rented accommodation, is founded upon the 'flawed nature' of the neoliberal construction of the housing sector as market. The perceived need of this welfare cut is a direct consequence of the contraction of social housing and the deregulation of the private rented sector, with the high Housing Benefit bill, which the reform seeks to tackle, 'itself an outcome of the failures of neoliberal housing policy' (Powell, 2015: 322).

Hall and O'Shea illustrate this 'strangely composite' nature of neoliberal common sense, making visible the 'unresolved struggle over common sense within the individual as well as between individuals and groups' (Hall and O'Shea, 2013: 14). Their conceptualisation of common sense as 'a site of political struggle' (2013: 3), focussing attention on the processes through which common sense is established, redefines its production as a moment of politics. As Rancière suggests, "politics makes visible that which a social order wishes to render invisible (Chambers, 2011:305). In this way, politics is a moment, an act, or a representation that challenges the ontological premise of a given frame at any one time. Through disruption, politics renders visible the possible limits of established knowledge and ways of representing this. Conceptualising common sense as a site of politics, highlights its performative nature, though moments of politics may act as fleeting ruptures, they are formative of a police order:

'an order of bodies that defines the allocation of ways of doing, ways of being, and ways of saying, and sees that those bodies are assigned by name to a particular place and task; it is an order of the visible and the sayable' (Rancière, 1999: 29)

Understood in this way, academic representations of the housing market are entangled with formations of neoliberal common sense, they are constitutive of 'ways of doing, ways of being, and ways of saying' (Rancière, 1999). As Allen (2010) highlights, much housing research has accepted the neoliberal construction of housing, positioning the market as "something they should "observe", "understand" and "manage" rather than critique' (Allen, 2010: 138). Consequently, housing research produces 'knowledge' about the 'housing market', in turn legitimising 'the hegemonic view of the market' (2010: 139). In line with Allen's critique, I suggest thinking with Rancière's conceptualisation of politics enables a critical engagement with academic representations of neoliberal formations of home through an exploration of the ways they (re)constitute that which they critique.

\section{Common sense as political struggle: A right to home?}

The use of a 'cultural political' methodology to 'examine the mechanisms through which... sentiments are produced and mediated' (Jensen and Tyler, 2015: 1), enables a tracing of the histories of political values, locating claims to common sense within a moral economy. Thus, a sociological analysis of common sense may facilitate the 'unpicking of...mechanisms of consent' (Jensen and Tyler, 2015: 29). That is, by emphasising ways in which common sense representations 'generate divergent, resistant and multifarious meanings and affects' (Allen, Tyler and De Benedictis 2014: 2.5), there may be an opportunity to fracture this imaginary (Jensen and Tyler, 2015).

The conceptualisation of common sense as a site of political struggle draws attention to the processes through which common sense is produced, reproduced, legitimised and policed (Hall and O'Shea, 2013). This more dynamic account of common sense brings to the fore temporality and change. Through a focus on the composite formations of common sense, dominant discourses do not negate dissensus. Rather, common sense may be conceived as a site of dissensus and, as such, a productive site. 
As Humphrey's (2017) analysis of the aftermath of Grenfell Tower fire suggests, there have been moments where voices previously silenced have demanded recognition 'as speakers who speak, rather than emit noise or ventriloquize' (Pelletier, 2009: 276). There has been resistance to the censorship of affect, challenging dominant representations of 'whose life is grievable' (Butler, 2012). Interviews with residents are one such site of politics, where the dominant framing of the fire is 'contextualised within the wider structural inequalities that scar our present historical moment' (Humphrey, 2017).

'.. you can pause me there, but I'm not going to lie. The whole situation that's going on in this area, the way that they don't want us here, and they put those rich man's blocks over there, and they tell certain man in Frinstead that they can't even go into that section, that's outrageous. I can't lie, the way they treat man in here it's terrible innit, so I can't even take the belief out of my mind was that that wasn't just an accident, do you know what I'm saying? I'm not going to lie, I think it's fucked' (Peaky Saku speaking on BBC news $14^{\text {th }}$ June)

Despite attempts to shut down the interview, Peaky Saku resisted the silencing of his voice, powerfully articulating his experience and locating the fire within processes of gentrification, symbolic violence and systemic devaluing of working class lives. The affective responses of those devastated by the fire are often delegitimised within media exchanges, with the interviewer in this example closing with an apology for the language used. Yet, the sharing of such moments which rupture across social media may hold open the speech of residents as a site of politics challenging the dominant representation of mainstream media.

As the causes of the fire and its spread begin to be exposed and contextualised, the neoliberal common sense of housing as market, whereby housing is 'produced in commodity form for surplus value extraction', is 'revealed in all [its] brutality' (Watt, 2017a). The foundation of neoliberal housing policy on a privileging of exchange values of 'housing-as-property' over use values, of 'home and need', have been made explicit in sociological critique following the fire (Watt, 2017a). However, with the terms of the public inquiry failing to examine the social and political context of the fire, it becomes crucial for further sociological analysis of the conditions in which a fire such as that at Grenfell Tower is able to occur. As Humphrey suggests, 'the quest for justice must drill down to the underpinning practices of neoliberal economics... and replace the associated individualistic values with an alternative ethic of equality and care' (Humphrey, 2017).

This paper aims to provide a starting point for such an analysis. Drawing upon Butler's conceptualisation of precarity (Butler, 2011), I have sought to locate the fire at Grenfell Tower within the structural conditionality of home. Mapping transformations in the form and philosophy of social housing, I argue that contemporary housing policy undermines the right to home, actively (re)producing exclusions and inequality (Slater, 2013). Through a critical reading of the construction of ideologically driven policies as common sense, the paper provides an analysis of the housing market as neoliberal common sense, foregrounding the 'mechanisms of consent' (Jensen and Tyler, 2015: 29) which cultivate national affect. An emphasis on the composite quality of neoliberal common sense highlights its formation as a process of political struggle. This paper suggests that the fire at Grenfell Tower may be understood as a site of politics, where critique of the structural formation of the 'ideals' of home ownership expose of the symbolic violence they commit on those living in social housing (Allen, 2010).

It is within this context that I argue for a right to home as form of 'radical hope' (Lear, 2006); a 'faith that an as-yet-articulated but better future can be created despite a devastated present' (Madden, 2017: 4). With reference to Watt's call for a 'right to the city' (Watt, 2017b), I assert a right to home as the right to be 'physically present' (Purcell; 2002), the right to inhabit rather than to own. A first step in 
establishing a right to home is the detangling of citizenship from market engagement. The recognition of those beyond the logics of capitalist modes of production, both in terms of the labour market and housing market, as embodying the rights to home, is integral to challenging the 'violence and inequality of the UK's particular brand of neoliberal capitalism' (Madden, 2017:3) and replacing it with an ethic of equality and care.

\section{Bibliography}

Allen, K., Tyler, I. and De Benedictis, S. (2014). 'Thinking with "White Dee": The Gender Politics of Austerity Porn'. Sociological Research Online, 19(3).

BBC News (2017). 'Grenfell Tower fire: sweary eye witness on BBC news', (video online) [Available at https://www.youtube.com/watch?v=3d-oYLZJsWI].

Butler, J. (2011). For and against precarity. Tidal: Occupy Theory, Occupy Strategy, 1, pp.12-13.

Butler, J. (2012). 'Precarious Life, Vulnerability, and the Ethics of Cohabitation, Journal of Speculative Philosophy, 26(2), pp. 134-151.

Butler, J. and Athanasiou, A. (2013). Dispossession: The performative in the political. John Wiley \& Sons.

Chambers, S.A. (2011). 'Jacques Rancière and the Problem of Pure Politics', European Journal of Political Theory, 10(3), pp. 303-326.

Clarke, J. and Newman, J. (2012). ‘The Alchemy of Austerity', Critical Social Policy, 32(3), pp. 299319.

Crawford, J. and McKee, K. (2018). Privileging the "Objective": Understanding the State's Role in Shaping Housing Aspirations. Housing, Theory and Society, 35(1), pp.94-112.

Featherstone, M. (2013) "Being-in-Hull, Being-on-Bransholme: Socio-economic Decline, Regeneration and Working-Class Experience on a Peri-Urban Council Estate", City: Analysis of Urban Trends, Culture, Theory, Policy, Action, 17(2), pp. 179-196.

Garbin, D. and Millington, G. (2012). Territorial stigma and the politics of resistance in a Parisian banlieue: La Courneuve and beyond. Urban studies, 49(10), pp.2067-2083.

Hall, S. and O'Shea, A. (2013). 'Common-Sense Neoliberalism. Soundings: A Journal of Politics and Culture, 55(1), pp. 8-24.

Hancock, L. and Mooney, G. (2013). "Welfare ghettos" and the "broken society": Territorial stigmatization in the contemporary UK. Housing, Theory and Society, 30(1), pp.46-64.

Hanley, L. (2007). Estates: An Intimate History. London: Granta.

Harvey, D. (2007). A brief history of neoliberalism. Oxford University Press, USA.

Hubbard, P. and Lees, L. (2018). The right to community? Legal geographies of resistance on London's gentrification frontiers. City, 22(1), pp.8-25.

Humphrey, D. (2017). "“Those people in there, like the phoenix shall rise from the ashes, the truth shall come out": voices and analysis, Grenfell Tower', [Blog] City: Critical analysis of urban trends, culture, 
theory, policy, action. Available at http://www.city-analysis.net/2017/06/23/those-people-in-there-likethe-phoenix-shall-rise-from-the-ashes-the-truth-shall-come-out-debbie-humphry/

[Accessed 21/08/2017].

Jacobs, K. and Manzi, T. (2013). 'New localism, old retrenchment: The "Big Society", housing policy and the politics of welfare reform', Housing, Theory and Society, 30(1). pp.29-45.

Jensen, T. (2014). 'Welfare Commonsense, Poverty Porn and Doxosophy'. Sociological Research Online, 19(3).

Jensen, T. and Tyler, I. (2015). "Benefits broods": The Cultural and Political Crafting of Anti-Welfare Commonsense'. Critical Social Policy, 35(4), pp. 1-22.

Kadi, J. (2015). Recommodifying housing in formerly "Red" Vienna? Housing, Theory and Society, 32(3), pp.247-265.

Lear, J. (2006). Radical Hope: Ethics in the Face of Cultural Devastation, Cambridge, MA: Harvard University Press.

Madden, D.J. (2017). 'Editorial: A catastrophic event', City, 21(1), pp. 1-5.

Moffatt, S., Lawson, S., Patterson, R., Holding, E., Dennison, A., Sowden, S. and Brown, J. (2015). 'A Qualitative Study of the Impact of the UK 'Bedroom Tax'. Journal of Public Health, pp. 1-9.

Pelletier, C. (2009). 'Rancière and the Poetics of the Social Sciences'. International Journal of Research \& Method in Education, 32(3), pp. 267-284.

Powell, R. (2015). 'Housing Benefit Reform and the Private Rented Sector in the UK: On the Deleterious Effects of Short-term, Ideological "Knowledge", Housing, Theory and Society, 32(3), pp.320-345.

Purcell, M. (2002). 'Excavating Lefebvre: The right to the city and its urban politics of the inhabitant', GeoJournal, 58, pp. 99-108.

Rancière, J. (1999) [1995]. Disagreement: Politics and Philosophy. Minneapolis: University of Minnesota Press.

Robinson, D. and Walshaw, A. (2014). 'Security of tenure in social housing in England', Social Policy and Society, 13(1), pp.1-12.

Sassen, S., 2014. Expulsions: Brutality and complexity in the global economy, Harvard University Press.

Savage, M., Allen, C., Atkinson, R., Burrows, R., Méndez, M.L., Watt, P. and Savage, M. (2010), 'Focus article', Housing, theory and society, 27(2), pp.115-161.

Shildrick, T. and MacDonald, R. (2013). Poverty talk: how people experiencing poverty deny their poverty and why they blame 'the poor'. The Sociological Review, 61(2), pp.285-303.

Skeggs, B. (2004). Class, Self, Culture. London: Routledge.

Slater, T. (2013). 'The myth of "Broken Britain": welfare reform and the production of ignorance', Antipode, 46(4), pp. 948-969. 
Tyler, I. (2013). Revolting Subjects: Social Abjection and Resistance in Neoliberal Britain, London: Zed Books.

Tyler, I. (2015). Classificatory struggles: Class, culture and inequality in neoliberal times. The Sociological Review, 63(2), pp.493-511.

Wacquant, L. (2010). 'Crafting the neoliberal state: Workfare, prisonfare, and social insecurity, Sociological Forum, 25(2), pp. 197-220.

Watt, P. (2017b). 'Gendering the right to housing in the city: homeless female lone parents in postOlympics, austerity East London', Cities, in press, pp. 1-9.

Watt, P. (2017a). "'This place is post-something" - London's housing in the wake of the Grenfell Tower fire', [Blog] City: Critical analysis of urban trends, culture, theory, policy, action. Available at http://www.city-analysis.net/2017/06/23/this-place-is-post-something-londons-housing-in-the-wakeof-the-grenfell-tower-fire-paul-watt/ [Accessed 21/08/2017]. 